\title{
CITA HUKUM DAN SISTEM NILAI ETIKA ADVOKAT DALAM PENYELESAIAN SENGKETA HUKUM KELUARGA ISLAM
}

\author{
Jefry Tarantang
}

Institut Agama Islam Negeri Palangka Raya, Kalimantan Tengah, Indonesia

hukumtarantang@gmail.com

Received:11-06-2019; Revised: 14-06-2019; Accepted: 20-12-2019

\begin{abstract}
The purpose of the advocacy process in resolving Islamic family law disputes is to bring about justice, so that it requires treatment and advocacy in accordance with Islamic teachings that originate from the Koran and hadith by promoting commendable morals. This condition is a legal ideal (rechtsidee) and an ethical value system for advocates in resolving Muslim family law disputes. This research is a normative legal research with a statue approach, a conceptual approach and a philosophical/ushul fiqh approach (philosophy of Islamic law approach) then analyzed qualitatively. The ideals of the law and the ethical value system of advocates in the resolution of Islamic family law disputes are not limited to justice in positive law but also explore broader values and principles beyond positive law. These values and principles can be found through legal foundations and principles, namely the foundation of the Koran and Hadith, the basis of laws and regulations consisting of Pancasila and the 1945 Constitution, Law Number 18 of 2003 Concerning Advocates, and the Indonesian Advocate Code of Ethics for the Year 2002, philosophical foundation, theoretical foundation, juridical foundation, and sociological foundation which become advocate ethical values system through values, norms, and morals that have concepts and are interrelated and complement each other in the advocate ethics system through basic values then are translated into instrumental and concrete values be a praxis value in resolving Islamic family law disputes.

Keywords: Legal ideals, value system, advocate ethics, dispute resolution, Islamic family law.
\end{abstract}

\section{INTISARI}

Tujuan dari proses advokasi dalam penyelesaian sengketa hukum keluarga Islam yaitu mewujudkan keadilan, sehingga membutuhkan perlakuan dan advokasi yang sesuai dengan ajaran Islam yang bersumber dari Alquran dan hadis dengan mengedepankan akhlak terpuji. Kondisi tersebut menjadi cita hukum (rechtsidee) dan sistem nilai etika advokat dalam penyelesaian sengketa hukum keluarga Islam. Penelitian ini merupakan penelitian hukum normatif dengan pendekatan peraturan perundang-undangan (statue approach), pendekatan konseptual (conceptual approach) dan pendekatan filsafat hukum/ ushul fikih (philosophy of Islamic law approach) kemudian dianalisis secara kualitatif. Cita hukum dan sistem nilai etika advokat dalam penyelesaian sengketa hukum keluarga Islam tidak terbatas pada keadilan dalam hukum positif saja tetapi juga menggali nilai-nilai dan prinsip-prinsip yang lebih luas di luar hukum positif. Nilai-nilai dan prinsip-prinsip tersebut dapat ditemukan melalui landasan dan kaidah hukum yaitu landasan Alquran dan hadis, landasan peraturan perundangan-undangan yang terdiri dari Pancasila dan UUD 1945, Undang-Undang Nomor 18 Tahun 2003 
Tentang Advokat, dan Kode Etik Advokat Indonesia Tahun 2002, landasan filosofis, landasan teoritis, landasan yuridis, dan landasan sosiologis yang menjadi sistem nilai etika advokat melalui nilai, norma, dan moral yang memiliki konsep dan saling berkaitan dan saling melengkapi dalam sistem etika advokat melalui nilai dasar kemudian dijabarkan menjadi nilai instrumental dan konkret menjadi nilai praksis dalam penyelesaian sengketa hukum keluarga Islam.

Kata Kunci: Cita hukum, sistem nilai, etika advokat, penyelesaian sengketa, hukum keluarga Islam.

\section{A. Pendahuluan}

Perkembangan profesi advokat, khususnya dalam penyelesaian sengketa hukum keluarga Islam di Indonesia selama ini lebih banyak mengedepankan aspek yuridis formal secara legal formal yang terkonsep secara litigasi di pengadilan agama yang berujung pada putusan pengadilan. ${ }^{1}$ Secara sosiologis, hal ini menunjukkan adanya advokasi penyelesaian sengketa hukum keluarga yang mendasarkan diri pada otoritas dan menggunakan forum-forum yang dapat dipertanggungjawabkan menurut peraturan perundang-undangan dan prinsip-prinsip hukum saja yaitu lembaga peradilan agama. ${ }^{2}$ Meskipun demikian, konsep penyelesaian sengketa hukum keluarga secara litigasi di pengadilan agama tersebut tidak dapat sepenuhnya menyelesaikan sengketa hukum keluarga, bahkan dapat menambah sengketa yang berkepanjangan antara anggota keluarga. Sehingga penyelesaian sengketa secara non litigasi di luar pengadilan $^{3}$ melalui konsep alternatif penyelesaian sengketa hukum keluarga Islam memerlukan pengembangan peraturan perundang-undangan yang mengatur etika advokat dalam penyelesaian sengketa hukum keluarga Islam.

Advokat sebagai penegak hukum yang dikenal membela kliennya secara maksimal sudah lama dikenal dalam sejarah hukum. Pada tahun 1820, Advokat Henry Brougham (dari Inggris) yang merupakan partner dari Bentham dalam mendirikan University of London, ketika membela Queen Caroline dalam membela kliennya tersebut telah membela kliennya secara habis-habisan. Bahkan, sampai menjatuhkan kewibawaan Raja George IV, dengan membuka fakta bahwa Raja George IV melakukan pengikatan perkawinan dengan seorang beragama Katolik Roma, sehingga

\footnotetext{
${ }^{1}$ Jefry Tarantang, Advokat Mulia (Paradigma Hukum Profetik dalam Penyelesaian Sengketa Hukum Keluarga Islam), Yogyakarta: K-Media, 2018, h. 208.

${ }^{2}$ Philippe Nonet, dan Philip Selznick, Hukum Responsif, diterjemahkan oleh Raisul Muttaqien dari buku asli berjudul "Law and Society in Transition: Toward Responsive Law", Bandung: Nusa Media, 2013, h. 106-109.

${ }^{3}$ Jefry Tarantang, Penyelesaian Sengketa Melalui Lembaga Arbitrase, Jurnal Al-Qordh Volume 4, Nomor 2, 2018, h. 111.
} 
Raja secara otomatis harus kehilangan mahkotanya sebagai raja. Sejak itu, prinsip membela klien mati-matian ini berlaku sebagai hukum etika bagi advokat. ${ }^{4}$

Advokat yang membela klien secara habis-habisan inilah kemudian muncul istilah advokat sebagai senjata sewaan (hired gun), yang seolah-olah advokat seperti tukang pukul sewaan, yang siap mempertaruhkan nyawanya demi kliennya. Sayang, lama kelamaan istilah advokat sebagai senjata sewaan ini dalam perkembangannya lebih berkonotasi negatif, dalam arti advokat demi kliennya dapat melakukan apa saja termasuk melakukan hal-hal yang tidak halal, seperti berbohong, mengancam lawan klien dan lain-lain. ${ }^{5}$

Keberadaan advokat yang atau diidentikkan dengan "membela yang bayar" yaitu advokat berjuang membela mati-matian untuk membela kliennya. Dalam kemampuannya bersilat lidah dan bermain kata-kata, advokat sering dianggap mampu menghitamkan yang putih dan memutihkan yang hitam. la bisa membuat bebas klien yang bersalah atau membuat kliennya mendapat sesuatu yang bukan haknya. Idealismenya bukan membela kebenaran, melainkan membela klien. Tidak heran jika kesan yang melekat pada advokat memiliki "reputasi" semakin ia menang membela klien, semakin dicari orang dan bayarannya semakin tinggi. Pada sisi lain, ada pula sebagian orang yang memberikan pandangan miring terhadap profesi advokat seperti "gunting" kedua sisi gunting saling bersinggungan dan berlawanan, tetapi yang terjepit dan koyak adalah kain yang berada di tengah-tengah kedua sisi tersebut. Dua orang advokat bisa berdebat sengit di pengadilan membela kliennya masing-masing, tetapi di luar pengadilan mereka mungkin akan saling bertanya, "Berapa penghasilan yang kamu dapatkan dari klienmu?" Tentu, ini sebuah ironi tatkala profesi advokat atau pengacara dipandang sebagai pekerjaan mulia (prodeo atau officium nobile), tetapi disalahgunakan menjadi pekerjaan yang mengabaikan kebenaran dan keadilan. ${ }^{6}$

\footnotetext{
${ }^{4}$ Ibid., h. 157.

${ }^{5}$ Satjipto Rahardjo menjelaskan bahwa Gerry Spence mengkritik keprofesionalan advokat di Amerika Serikat ternyata menjadi kurang berarti, bahkan mengganggu, apabila tidak diarahkan kepada tujuan kemanusiaan yang lebih tinggi. Kritik terhadap mereka tersebut ditujukan kepada ketidakmampuan (incompetence] untuk memberikan pelayanan kepada publik. Masyarakat datang ke kantor-kantor advokat, karena mempunyai persoalan dengan keadilan. Mereka adalah orang-orang yang sedang susah dan menderita dan karena itu mereka berpikir untuk pergi ke advokat meminta bantuan agar keluar dari kesusahannya. Tetapi, para advokat berpikir lain, tidak seperti diharapkan oleh masyarakat. Mereka lebih melihat publiknya sebagai aset untuk mendapatkan keuntungan material, bukan sebagai orang susah yang memerlukan pertolongan. Lihat dalam Satjipto Rahardjo, Hukum Progresif Sebuah Sintesa Hukum Indonesia, Yogyakarta: Genta Publishing, 2009, h. 105.

${ }^{6}$ Didi Kusnadi, Bantuan Hukum dalam Islam Profesi Kepengacaraan dalam Islam dan Prakteknya, Bandung: Pustaka Setia, 2012, h. 248.
} 
Pandangan di atas tentu tidak semuanya benar, karena saat ini pun masih banyak advokat yang memiliki visi idealis dan bekerja sesuai hati nurani mereka, serta berjuang dalam menegakkan kebenaran dan keadilan. Mereka menjaga nilai-nilai moral dan etika, karena mereka adalah salah satu pilar penting dalam penegakan hukum dan keadilan. Akan tetapi, banyaknya advokat yang bermental gunting juga tidak dapat kita nafikan. Bukankah sudah sejak lama bangsa ini mengenal istilah "pokrol bamboo". 7 Namun, meskipun dikatakan bahwa advokat harus membela kliennya habis-habisan atau semaksimal mungkin, tentu saja membela klien itu ada batasnya, baik batas yuridis maupun batas etika. Dengan perkataan lain, ada norma hukum dan norma etika yang membatasi komitmen penuh advokat terhadap kliennya itu termasuk pula dalam penyelesaian sengketa hokum keluarga Islam.

\section{B. Metode Penelitian}

Penulisan penelitian ini menggunakan metode normatif melalui literatur kajian pustaka (library research) terhadap buku-buku yang berhubungan dengan tema penelitian yang dibuat, dan juga bersumber dari beberapa penelitian. Adapun pendekatan dalam pembahasan penelitian ini adalah pendekatan peraturan perundangundangan (statue approach), pendekatan konseptual (conceptual approach) dan pendekatan filsafat hukum/ ushul fikih (philosophy of Islamic law approach) kemudian dianalisis secara kualitatif. ${ }^{8}$

\section{Hasil dan Pembahasan}

\section{Hakikat Cita Hukum dan Tujuan Perumusan Nilai Moral dan Nilai Etik Advokat dalam Penyelesaian Sengketa Hukum Keluarga Islam}

Perumusan nilai dasar etika advokat dalam membentuk suatu cita hukum (rechtsidee) yang terdiri dari nilai-nilai moral dan nilai-nilai etik. Nilai-nilai moral merupakan pengetahuan manusia tentang nilai-nilai baik dan nilai-nilai buruk. Nilai baik dan buruk tersebut berada di luar jangkauan manusia, karena kedua macam nilai tersebut sudah ada di dalam diri manusia sejak saat dirinya dilahirkan. Sedangkan nilai etik tercermin dari sikap dan perilaku manusia terhadap nilai-nilai moral, yaitu nilai baik dan nilai buruk. ${ }^{9}$

\footnotetext{
${ }^{7}$ Ibid., h. 248-249.

${ }^{8}$ Jefry Tarantang, Teori dan Aplikasi Pemikiran Kontemporer dalam Pembaharuan Hukum Keluarga Islam, Jurnal Transformatif Vol. 2, No. 1, April 2018, h. 29.

${ }^{9}$ Sirajuddin, Perda Berbasis Norma Agama, Jakarta: Rajawali Pers, 2015, h. 203. Lihat juga Thomas E. Davitt, Nilai-Nilai Dasar di dalam Hukum Menganalisa Implikasi-Implikasi Legal-Etik Psikologi \& Antropologi bagi Lahirnya Hukum, Yogyakarta: Pallmal, 2012, h. 2.
} 
C.J.M. Schuyt berpandangan bahwa pada dasarnya hukum dapat diartikan sebagai suatu sistem jalinan nilai-nilai. ${ }^{10}$ Sistem merupakan serangkaian interaksi unitunit atau elemen-elemen yang membentuk sebuah keseluruhan terintegrasi yang dirancang untuk melaksanakan beberapa fungsi. ${ }^{11}$ Begitu pula dalam sistem nilai etika advokat dalam penyelesaian sengketa hukum keluarga Islam terdapat serangkaian interaksi elemen berupa prinsip etika yang membentuk etika advokat secara terintegrasi dalam advokasi penyelesaian sengketa hukum keluarga Islam.

Menurut Aristoteles, hukum menjadi pengarah manusia pada nilai-nilai moral yang rasional, maka hukum itu sendiri harus adil. Keadilan hukum identik dengan keadilan umum. Keadilan ditandai oleh hubungan yang baik antara satu dengan yang lain, tidak mengutamakan diri sendiri, tapi mengutamakan pihak lain, serta adanya kesamaan atau disebut dengan perasaan sosial etis. Formulasi Aristoteles mengenai prinsip keadilan bertumpu pada hidup secara terhormat, tidak menggangu orang lain, dan memberi tiap orang bagiannya (honeste vivere, alterum non laedere, suum quique tribuere). Keadilan merupakan alat praktis untuk mencapai kehidupan yang baik, adil, dan sejahtera. ${ }^{12}$ Hukum sebagai positivasi nilai moral adil bagi semua orang. Keadilan ini menuntut setiap penyelenggara negara untuk menempatkan kepentingan umum sebagai rujuan hukum. Tanpa moral, hukum tidak mengikat secara nalar karena moral mengutamakan pemahaman dan kesadaran subjek dalam mematuhi hukum. ${ }^{13}$ Begitu pula dalam konteks hukum Islam, dalam merumuskan konsep nilai etika advokat dalam penyelesaian sengketa hukum keluarga Islam juga menggunakan prinsip keadilan yang membawa kepada kemaslahatan keluarga, sebagaimana kaidah fikih:

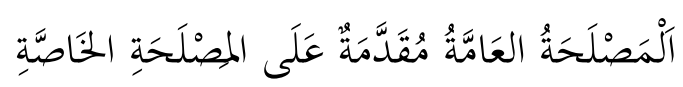

Artinya: Kemaslahatan publik didahulukan daripada kemaslahatan individu. ${ }^{14}$

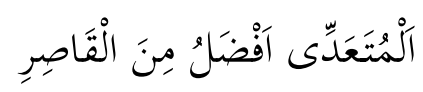

\footnotetext{
${ }^{10}$ A. Ridwan Halim, Bendera Mimbar Filsafat Hukum Indonesia dan Pragmatisasinya (Suatu Analisis Yuridis Empiris), Jakarta: Angky Pelita Studyways, 2004, h. 108.

${ }^{11}$ Jasser Auda, Membumikan Hukum Islam Melalui Maqasid Syariah, diterjemahkan oleh Rosidin dan 'Ali 'Abd el-Mun'im dari buku asli berjudul "Maqasid Shariah as Philosophy of Islamic Law: A System Approach", Bandung: Mizan Pustaka, 2015, h. 70.

${ }^{12}$ Lihat Bernard L. Tanya, dkk, Teori Hukum Strategi Tertib Manusia Lintas Ruang dan Generasi, Yogyakarta: Genta Publishing, 2010, h. 44-45.

${ }^{13}$ Muhammad Nuh, Etika Profesi Hukum, Bandung: Pustaka Setia, 2011, h. 211.

${ }^{14}$ A. Djazuli, Kaidah-kaidah Fikih: Kaidah-kaidah Hukum Islam dalam Menyelesaikan MasalahMasalah yang Praktis, Jakarta: Kencana, 2007, h. 11.
} 
Artinya: Perbuatan yang mencakup kepentingan orang lain lebih utama daripada yang hanya terbatas untuk kepentingan sendiri. ${ }^{15}$

Adanya pandangan positivisme hukum, seperti Hans Kelsen, memandang bahwa berdasarkan tatanan hukum positif atau rasio melalui logika keteraturan atau secara sistematis, keadilan adalah yang tertuang dalam hukum positif. Kepatuhan terhadap hukum positif dapat dikatakan adil, sementara tindakan di luar hukum positif dianggap tidak adil, atau dengan kata lain makna keadilan adalah keadilan yang diberlakukan dalam hukum positif. ${ }^{16}$ Pandangan positivistik semacam ini akan membatasi makna keadilan, artinya tidak ada pencarian keadilan di luar hukum positif. $^{17}$ Begitu pula dalam merumuskan konsep nilai etika advokat dalam penyelesaian sengketa hukum keluarga Islam tidak hanya terbatas pada hukum positif, sehingga menurut penulis pandangan positivistik Hans Kelsen di atas tidak relevan, sebab membatasi keadilan sebagai tujuan hukum hanya dalam hukum positif. Begitu pula advokat sebagai penegak hukum dalam berperilaku hendaknya tidak terbatas mengacu pada hukum positif atau hukum tertulis saja, seperti Undang-Undang Nomor 18 Tahun 2003 Tentang Advokat, dan Kode Etik Advokat Indonesia Tahun 2002.

Untuk mewujudkan nilai keadilan maka diperlukan sistem hukum untuk menjamin terciptanya keadilan dengan menerapkan peraturan hukum yang sesuai. ${ }^{18}$ Mengacu pada sistem hukum Indonesia yang majemuk. Sistem hukum dimaksud merupakan suatu mata rantai yang tidak dapat dipisahkan dalam proses pembentukan hukum nasional yang berasaskan Pancasila. Pancasila sebagai asas yang menjadi pedoman dan bintang pemandu terhadap norma hukum lainnya termasuk UndangUndang Dasar 1945, undang-undang, dan peraturan lainnya. Selain itu, menunjukkan bahwa sistem hukum Indonesia menjadikan Pancasila sebagai recht idee dan recht staat. Sistem hukum yang menjadikan Pancasila sebagai bintang pemandu dan sebagai hukum dasar negara. Selain itu, tampak pula bahwa Pembukaan UUD 1945 dengan

\footnotetext{
${ }^{15}$ Imam Musbikin, Qawa'id al-fiqhiyah, Jakarta: PT. RajaGrafindo Persada, 2001, h. 150-151.

${ }^{16}$ Anthon F. Susanto, Dekonstruksi Hukum Eksplorasi Teks dan Model Pembacaan, Yogyakarta: Genta Publishing, 2010, h. 90.

${ }^{17}$ Bandingkan dengan J.J. H. Bruggink, Refleksi tentang Hukum, diterjemahkan oleh Arief Sidharta dari buku asli yang berjudul "Rechtsreflecties", Bandung: Citra Aditya Bakti, 1999., h. 253.

${ }^{18}$ Lawrence M. Friedman, Sistem Hukum Perspektif Sosial, diterjemahkan oleh M. Khozim dari buku asli berjudul "The Legal System: A Social Science Perspective”, Bandung: Nusa Media, 2015, h. 19.
} 
peraturan perundang-undangan lainnya merupakan suatu kesatuan yang tidak terpisahkan. $^{19}$

Secara konkret hukum positif undang-undang mempunyai legalitas dan keberlakuannya menjadi acuan hukum kebiasaan dan kode etik, karena dibuat oleh penguasa (pembentuk undang-undang). ${ }^{20}$ Hal ini perlu disesuaikan dengan hukum tertinggi bagi umat Islam, khususnya advokat dalam menyelesaikan sengketa hukum keluarga Islam, oleh karena itu selain menjalankan profesi berdasarkan hukum positif harus menjunjung tinggi Alquran sebagai pedoman hidup yang utama. Sehingga diperlukan rumusan nilai dasar etika advokat yang menjadi sumber nilai dalam peraturan hukum konkret ${ }^{21}$ sebagaimana terdapat dalam Undang-Undang Nomor 18 Tahun 2003 tentang Advokat, dan Kode Etik Advokat Indonesia Tahun 2002 yang menjadi pedoman advokat sebagai aparat penegak hukum.

Lebih lanjut menurut Satjipto Rahardjo, aparat penegak hukum perlu memiliki kemampuan membaca kaidah, bukan membaca peraturan. Berhenti pada pembacaan undang-undang sebagai peraturan bisa menimbulkan kesalahan besar karena kaidah yang mendasari peraturan menjadi terlupakan. Kaidah adalah makna spiritual, roh. Sedangkan peraturan adalah penerjemahan ke dalam kata-kata dan kalimat. Membaca undang-undang tidak salah, tetapi hanya berhenti sampai di situ saja bisa membawa malapetaka. Logika peraturan hanya salah satu. Selain itu ada logika kepatuhan sosial (social reasonableness) dan ada pula logika keadilan/keadilan hukum (iustitia legalis). ${ }^{22}$ Dengan berpegang pada prinsip di atas, aparat penegak hukum, khususnya advokat berpeluang melakukan penegakan hukum secara progresif, terutama dalam penyelesaian sengketa hukum keluarga Islam.

\footnotetext{
${ }^{19}$ Zainuddin Ali, Hukum Islam (Pengantar Hukum Islam di Indonesia), Jakarta: Sinar Grafika, 2008, h. $83-84$.

${ }^{20}$ Hukum positif (positivisme) sebagai penentu berlakunya suatu hukum secara sah yang diperundangkan sesuai dengan prosedur perundangan yang berlaku. Ini berarti, otoritas merupakan penentu hukum positif yang menjamin kepastian hukum. Lihat Muhammad Nuh, Etika Profesi Hukum, Bandung: Pustaka Setia, 2011, h. 210.

${ }^{21}$ Peraturan hukum konkret ialah peraturan hukum yang dituangkan dalam bentuk tertulis yang tampak dalam bentuk pasal atau kalimat-kalimat. Hukum konkret bagi sebagian sarjana hukum didefinisikan sebagai himpunan peraturan-peraturan hukum yang mengatur kegiatan kehidupan manusia yang dapat dipaksakan pelaksanaannya. Dikatakan bagi sebagian besar sarjana hukum karena bagi sebagian sarjana hukum lain hukum tidak dilihat sebagai himpunan peratuan. Sebagian besar sarjana hukum (hakim, jaksa, dosen, pengacara dan sebagainya) pada umumnya dihadapkan pada peristiwa konkret yang memerlukan pemecahan suatu konflik. Untuk memecahkan peristiwa konkret atau konflik tersebut dicarikan norma atau hukumnya dan hukumnya terdapat dalam himpunan peraturan-peraturan hukum. Lihat Sudikno Mertokusumo, Penemuan Hukum, Yogyakarta: Universitas Atma Jaya, 2010, h. 18.

${ }^{22}$ Lihat Bernard L. Tanya, dkk, Teori Hukum Strategi Tertib Manusia Lintas Ruang dan Generasi, Yogyakarta: Genta Publishing, 2010, h. 62-63.
} 


\section{Landasan dan Kaidah Hukum Rumusan Nilai Etika Advokat dalam Penyelesaian Sengketa Hukum Keluarga Islam}

Landasan etika advokat dalam penyelesaian sengketa hukum keluarga Islam berkaitan dengan status profesi advokat sebagai profesi hukum harus memperhatikan beberapa prinsip agama Islam yang terdapat dalam Alquran dan hadis yaitu prinsip $a m a>n a>t$ dan adil, prinsip perdamaian, prinsip advokasi penyelesaian sengketa, prinsip penyelesaian sengketa keluarga, dan juga prinsip musyawarah yang relevan dijadikan landasan etika advokat dalam penyelesaian sengketa hukum keluarga Islam. Sebab, prinsip-prinsip tersebut akan menjadi kaidah hukum bagi advokat. Kaidah hukum tersebut berdasarkan kewenangan advokat, yaitu peraturan atributif dan peraturan normatif. ${ }^{23}$ Kedua kaidah hukum tersebut memberikan landasan operasional bagi advokat melalui landasan operasional yang bersifat umum dan landasan operasional yang bersifat umum. Landasan yang bersifat umum, yaitu peraturan perundang-undangan mengenai profesi advokat yaitu Undang-Undang Nomor 18 Tahun 2003 tentang Advokat dan Kode Etik Advokat Indonesia Tahun 2002, dan segala perangkat aturan perundang-undangan yang berkaitan dengan hukum materil terkait penyelesaian sengketa hukum keluarga Islam. Adapun landasan operasional yang bersifat khusus, yaitu norma-norma atau kaidah yang wajib ditaati para penegak hukum atau pemelihara hukum termasuk advokat memiliki norma-norma atau kaidah yang wajib ditaati.

Adanya pandangan yang memisahkan atau mendikotomikan antara asas agama dan asas hukum merupakan tantangan dalam merumuskan konsep nilai dan sistem nilai etika advokat berdasarkan norma agama atau hukum Islam, seperti pandangan yang dikemukakan Montesquieu bahwa agama memiliki keagungan yang lebih besar, sementara hukum sipil memiliki jangkauan yang lebih luas. Tidak hanya itu dengan tegas Montesquieu menyatakan bahwa:

Hukum kesempurnaan yang berasal dari agama lebih memandang kebaikan seorang individu yang melakukannya daripada masyarakat di mana kebaikan itu dilakukan. Sebaliknya hukum sipil lebih memandang kebaikan moral manusia secara umum daripada kebaikan seorang individu. Dengan demikian betapa pun mulianya gagasan-gagasan yang berasal dari agama, gagasangagasan itu tidak selalu dapat berlaku asa bagi hukum sipil; karena hukum sipil

\footnotetext{
${ }^{23}$ Henry Pandapotan Panggabean, Manajemen Advokasi, Bandung: Alumni, 2012, h. 14.
} 
memiliki sesuatu yang lain, yang harus diutamakan, yaitu kesejahteraan masyarakat secara keseluruhan. ${ }^{24}$

Tentunya pandangan Montesquieu itu beralasan pada pemisahan antara agama dan negara, namun dalam ajaran Islam seluruh aspek kehidupan manusia termasuk bernegara dan beragama tidak ada pemisahan seperti yang dikemukakan oleh Montesquieu, sebab dalam bernegara juga merupakan cerminan dari konsep beragama. Penulis menilai, berdasarkan pandangan hidup bangsa Indonesia yaitu Pancasila memberikan konsep hidup beragama melalui sila pertama Ketuhanan Yang Maha Esa, dan juga konsep bernegara yaitu sila ketiga Persatuan Indonesia, sehingga menurut penulis tidak ada pemisahan antara agama dan negara. Justru ajaran agama menjadi asas hukum dalam pembentukan hukum sipil di Indonesia. Begitu juga dalam merumuskan konsep nilai dan sistem nilai etika advokat dalam penyelesaian sengketa hukum keluarga Islam yang nota bene menggunakan norma agama yang bersifat mulia dan memiliki nilai universalitas bagi martabat dan keberadaban manusia. Ajaran agama mengandung prinsip moral utama yaitu takut kepada Allah SWT. Isi janji/sumpah jabatan profesi advokat selamanya didasarkan pada prinsip moral utama tersebut.

Agama menduduki posisi sentral dalam proses penegakan dan pembangunan hukum. Agama mengandung 2 (dua) aspek peranan dalam kehidupan bermasyarakat, peranan sebagai tuntunan kehidupan spiritual yang biasa disebut dogma agama. Dogma agama adalah wahyu ilahi yang memiliki kadar nilai kekekalan yang tidak mungkin dinilai dari aspek logika insani. Peranan sebagai tatanan kehidupan spiritual. Sebagai tatanan kehidupan spiritual dapat didekati untuk pengembangannya melalui etika agama. Etika agama berperan sebagai pembimbing tingkah laku manusia agar mampu mencapai kebahagiaan dalam aspek insani dan aspek Illahi melalui prinsip moral takut kepada Allah SWT. ${ }^{25}$

Norma agama yakni iman kepercayaan menuntut tanggung jawab dan menjadi orientasi moral bagi advokat yang menganut iman kepercayaan, setiap ajaran agama memuat ajaran moral agama yang sangat diperlukan untuk memotivasi kinerja profesi hukum yang sesuai tanggung jawab profesi. $^{26}$ Sedangkan norma negara yang

\footnotetext{
${ }^{24}$ Montesquieu, The Spirit of Laws Dasar-Dasar Ilmu Hukum dan Ilmu Politik, diterjemahkan oleh M. Khoiril Anam dari buku asli berjudul "The Spirit of Laws", Bandung: Nusa Media, 2015, h. 344-345.

${ }^{25}$ Henry Pandapotan Panggabean, Manajemen Advokasi, Bandung: Alumni, 2012, h. 87-88.

${ }^{26}$ Ibid., h. 10.
} 
menetapkan norma-norma hukum dan peraturan perundang-undangan yang harus ditaati dengan diikuti sanksi hukum bagi pelanggarnya. Etika Pancasila dapat dirumuskan untuk dijadikan motivasi tanggung jawab profesi dengan uraian sebagai berikut:

a. Visi yaitu negara dan Ketuhanan Yang Maha Esa dan kebangsaan yang didasari keberagaman budaya, Bhineka Tunggal Ika

b. Misi yaitu persatuan Indonesia (unity) dan demokrasi dilandasi prinsip moral musyawarah mufakat.

c. Tujuan yaitu kemakmuran yang berkeadilan diseluruh nusantara (welfare state). ${ }^{27}$

Agama berperan sebagai pembimbing tingkah laku manusia agar mampu mencapai kebahagiaan dalam aspek insani dan aspek ilahi melalui prinsip takut kepada Allah SWT. Frans Magnis Suseno menyatakan ada 4 (empat) alasan untuk melakukan pendekatan etika, yaitu:

a. Etika dapat membantu dalam menggali rasionalitas dan moralitas agama;

b. Etika membantu dalam menginterpretasikan ajaran agama yang saling bertentangan;

c. Etika dapat membantu penerapan ajaran moral agama terhadap masalah-masalah baru dalam kehidupan manusia.etika dapat membantu mengadakan dialog antar agama karena etika mendasarkan pada argumentasi rasional belaka bukan pada wahyu.

d. Pendekatan etika agama tersebut sangat relevan untuk dijadikan landasan perilaku para profesional, sehingga kapasitas profesional para penegak hukum dapat berkembang sejalan dengan realitas sosial yang dihadapi mereka dalam proses penegakan hukum. ${ }^{28}$

Etika advokat dalam penyelesaian sengketa hukum keluarga Islam, bila dilihat dari segi lapisan hukum, sebagaimana diungkapkan J. Gijssels dan Marck van Hoecke terdiri dari: pertama, dogmatik hukum (technischjuridish begrippen) teknis yuridis yang bersifat normatif, kedua, teori hukum (aglemene begrippen) analitis yang bersifat normatif empiris, dan ketiga, filsafat hukum (grondbegrippen) reflektif yang bersifat spekulatif. ${ }^{29}$ Begitu pula lapisan hukum etika advokat dalam penyelesaian sengketa hukum keluarga Islam terdiri dari filsafat hukumnya yaitu prinsip-prinsip atau nilai dasar etika advokat, teori hukumnya adalah kaidah hukum yang menjadi

\footnotetext{
${ }^{27}$ Ibid., h. 10 .

${ }^{28}$ Ibid., h. 88 .

${ }^{29}$ Philipus M. Hadjon, dan Tatiek Sri Djatmiati, Argumentasi Hukum, Yogyakarta: Gajah Mada
} University Press, 2016, h. 9-11. 
moralitas advokat, dan dogmatik hukumnya adalah peraturan hukum kongkret ${ }^{30}$ berupa etika advokat dalam penyelesaian sengketa hukum keluarga Islam.

Lebih lanjut menurut penulis, dalam merumuskan nilai dasar etika advokat dalam penyelesaian sengketa hukum keluarga Islam tidak terbatas pada keadilan dalam hukum positif saja tetapi juga menggali nilai-nilai dan prinsip-prinsip yang lebih luas di luar hukum positif. Nilai-nilai dan prinsip-prinsip tersebut dapat ditemukan melalui landasan etika yaitu landasan Alquran dan hadis, landasan peraturan perundangan-undangan yang terdiri dari Pancasila dan UUD 1945, UndangUndang Nomor 18 Tahun 2003 Tentang Advokat, dan Kode Etik Advokat Indonesia Tahun 2002, landasan filosofis, landasan teoritis, landasan yuridis, dan landasan sosiologis yang menjadi sistem etika advokat melalui nilai, norma, dan moral yang memiliki konsep dan saling berkaitan dan saling melengkapi dalam sistem etika advokat.

Kajian tentang etika berkaitan dengan nilai (value) yang mempertanyakan apakah yang "baik" dan "tidak baik" atau bagaimana "mesti" berbuat "baik" serta tujuannya bernilai. Hal ini menyentuh pertanyaan, apa dasar yang menjadi pembenaran suatu keputusan moral ketika disebut "baik" atau "tidak baik". ${ }^{31}$ Sehingga dalam merumuskan etika juga memerlukan nilai dasar. Nilai dasar merupakan nilainilai dasar yang mempunyai sifat tetap (tidak berubah), nilai dasar etika advokat dalam penyelesaian sengketa hukum keluarga Islam berdasarkan landasan Alquran dan hadis, landasan peraturan perundangan-undangan yang terdiri dari Pancasila dan UUD 1945, Undang-Undang Nomor 18 Tahun 2003 Tentang Advokat, dan Kode Etik Advokat Indonesia Tahun 2002, landasan filosofis, landasan teoritis, landasan yuridis, dan landasan sosiologis terdapat dalam Pembukaan UUD 1945 yang mencakup nilainilai instrumental dan nilai praksis.

Sebagaimana nilai-nilai yang terdapat dalam Pancasila yaitu ketuhanan, kemanusiaan, persatuan, kerakyatan (musyawarah) dan keadilan kemudian dijabarkan menjadi nilai-nilai instrumental dan nilai praksis yang lebih bersifat fleksibel dalam bentuk aturan atau norma-norma yang berlaku dalam kehidupan bemasyarakat,

\footnotetext{
${ }^{30}$ Peraturan hukum kongkret adalah ketentuan-ketentuan yang mengatur perilaku manusia, yang bersifat preskriptif dan berlaku umum, karena ditujukan secara umum untuk kelompok peristiwa atau kelompok situasi tertentu saja. Lihat Sudikno Mertokusumo, Teori Hukum, Yogyakarta: Cahaya Atma Pustaka, 2012, h. 50.

${ }^{31}$ Ayi Sofyan, Kapita Selekta Filsafat, Bandung: Pustaka Setia, 2010, h. 465.
} 
berbangsa dan bernegara. ${ }^{32}$ Hal tersebut juga menjadi nilai dasar etika advokat. Sedangkan nilai instrumental etika advokat adalah penjabaran lebih lanjut dari nilai dasar secara lebih kreatif dan dinamis dalam bentuk UUD 1945 dan peraturan perundang-undangan lainnya, dalam tata urutan peraturan perundang-undangan, seperti Undang-Undang Nomnor 18 Tahun 2003 Tentang Advokat, dan Kode Etik Advokat Indonesia Tahun 2002. Nilai instrumental ini dapat berubah atau diubah. Sedangkan nilai praktis etika advokat adalah nilai yang sesungguhnya dilaksanakan dalam kehidupan advokat dalam penegakan hukum, khususnya penyelesaian sengketa hukum keluarga Islam, seperti advokasi penyelesaian sengketa keluarga dengan menerapkan perdamaian. Nilai praksis juga dapat berubah/diubah sesuai dengan nilai dasar dan nilai intrumental. Maka nilai-nilai tersebut etika advokat berfungsi mensistematisasi moralitas advokat sesuai dengan nilai dasar etika advokat. ${ }^{33}$

Nilai dasar etika advokat dalam penyelesaian sengketa hukum keluarga Islam merupakan cerminan atau refleksi dari nilai-nilai yang terdapat dalam Pancasila yaitu ketuhanan, kemanusiaan, persatuan, kerakyatan (musyawarah), dan keadilan yang dibangun berdasarkan landasan-landasan berikut:

a. Landasan Alquran dan hadis yang terdiri dari prinsip perdamaian yang terdapat dalam Q.S. ali-Imra $>$ n [3]: 103, Q.S. an-Nisa $>$ [4]: 114, 128, dan Q.S. al-Hujura $>t$ [49]: 9-10, prinsip $a m a>n a>t$ dan adil yang terdapat dalam kandungan Q.S. anNisa $>$ [4]: 58, 105, 107, 111-113, 135, Q.S. al-Ma>idah [5]: 8, 49, Q.S. an-Nahl [16]: 90, 125, Q.S. al-Isra>' [17]: 36, dan Q.S. as $\{-\mathrm{S}\{\mathrm{a}>\mathrm{d}$ [38]: 26, prinsip advokasi penyelesaian sengketa yang terdapat dalam Q.S. an-Nisa> [4]: 35, 107, 109, 111113, Q.S. an-Nahl [16]: 90, 125, dan Q.S. as $\{-\mathrm{S}\{\mathrm{a}>\mathrm{d}[38]$ : 26, prinsip penyelesaian sengketa keluarga yang terdapat dalam kandungan Q.S. an-Nisa> [4]: 114, dan 128, dan prinsip musyawarah dalam penyelesaian sengketa yang terdapat dalam Q.S. asy-Syu>ra [42]: 38, dan Q.S. al-Hujura $>$ t [49]: 9-10. Adapun hadis yang menjadi landasan etika advokat dalam penyelesaian sengketa hukum keluarga Islam memiliki beberapa prinsip yaitu prinsip $a m a>n a>t$ dan adil, prinsip perdamaian, prinsip advokasi penyelesaian sengketa, prinsip penyelesaian sengketa keluarga, dan juga prinsip musyawarah yang relevan dijadikan landasan etika advokat dalam penyelesaian sengketa hukum keluarga Islam.

b. Landasan peraturan perundang-undangan terdiri dari Pancasila dan UUD 1945, Undang-Undang Nomor 18 Tahun 2003 Tentang Advokat, dan Kode Etik Advokat Indonesia Tahun 2002. Pancasila sebagai dasar negara yang dirumuskan dalam UUD 1945 memiliki nilai-nilai yang relevan dijadikan sebagai landasan etika advokat dalam penyelesaian sengketa hukum keluarga Islam yang menjadi pegangan dalam berbangsa dan bernegara, yaitu asas ketuhanan, asas

${ }^{32}$ Shidarta, Moralitas Profesi Hukum Suatu Tawaran Kerangka Berpikir, Bandung: Refika Aditama, 2009, h. 30-31.

${ }^{33}$ Lihat Cecep Sumarna, Rekonstruksi Ilmu: dari Empirik-Rasional Ateistik ke Empirik Rasional Teistik, Bandung: Benang Merah Press, 2005, h. 96. 
pengayoman, asas keadilan, asas kesamaan di depan hukum, dan asas kepastian hukum. Undang-Undang Nomor 18 Tahun 2003 tentang Advokat memiliki prinsip $a m a>n a>t$ dan adil dan juga prinsip advokasi penyelesaian sengketa yang memiliki kepastian hukum bagi advokat dalam penyelesaian sengketa hukum keluarga Islam. Sedangkan Kode Etik Advokat Indonesia Tahun 2002 menjadi landasan kode etik profesi yang juga memiliki prinsip $a m a>n a>t$ dan adil, prinsip perdamaian, prinsip advokasi penyelesaian sengketa, prinsip penyelesaian sengketa keluarga, dan juga prinsip musyawarah yang relevan dijadikan landasan etika advokat dalam penyelesaian sengketa hukum keluarga Islam.

c. Landasan filosofis etika advokat dalam penyelesaian sengketa hukum keluarga Islam adalah menciptakan kemaslahatan keluarga yang yaitu kemaslahatan keluarga win-win solution melalui islah (perdamaian) sebagai proses penyelesaian sengketa hukum keluarga di luar pengadilan (non litigasi). Sebab, apabila hanya mengutamakan aspek normativitas hukum saja yaitu kepastian melalui proses litigasi, maka dalam penyelesaian sengketa keluarga dapat menimbulkan kemudharatan win-lose yang dirasa tidak adil dan tidak memuaskan para pihak, sehingga tidak sesuai dengan landasan filosofis hukum Islam yaitu keadilan dan kemaslahatan.

d. Landasan teoritis etika advokat dalam penyelesaian sengketa hukum keluarga Islam, yaitu dibangun melalui konstruksi mental dan konstruksi intelektual yang dijadikan sebagai landasan teoritis. Secara teoritis, konstruksi mental etika advokat adalah $a m a>n a>t$ yang mengandung nilai kejujuran, objektivitas, dan adil. Sedangkan konstruksi intelektual etika advokat adalah profesional, yakni keahlian di bidang hukum (skill) dalam menyelesaikan sengketa hukum keluarga Islam, seperti sengketa perkawinan, sengketa putusnya perkawinan dan perceraian, sengketa perwalian, sengketa hak asuh (had\{a>nah), sengketa harta bersama, sengketa waris, sengketa wasiat, sengketa hibah, sengketa wakaf, sengketa zakat, sengketa infaq dan s\}ad \{aqah, baik secara non litigasi di luar pengadilan maupun secara litigasi dalam proses pengadilan.

e. Landasan yuridis etika advokat dalam penyelesaian sengketa hukum keluarga Islam merupakan landasan hukum yang terdiri dari landasan yuridis konstitusional yang terdapat dalam Pancasila (recht idee) dan Pasal 27 ayat (1), dan Pasal 28D ayat (1) UUD 1945, dan landasan yuridis normatif yang terdapat dalam Pasal 4 ayat (1) dan (2) Undang-Undang Nomor 18 Tahun 2003 tentang Advokat, dan Pasal 2 dan Pasal 4 huruf a Kode Etik Advokat Indonesia Tahun 2002 yang menjadi landasan yuridis etika advokat dalam penyelesaian sengketa hukum keluarga Islam.

f.Landasan sosiologis etika advokat dalam penyelesaian sengketa hukum keluarga Islam yaitu menjaga hubungan dalam interaksi para pihak yang bersengketa atau para klien khususnya anggota keluarga dalam sengketa keluarga yang menggunakan jasa advokat untuk mencari menciptakan kemaslahatan melalui budaya hukum yang hidup dan berkembang di masyarakat Indonesia, sebab pada dasarnya Indonesia mempunyai budaya penyelesaian sengketa secara damai melalui konsiliasi dan musyawarah, sehingga peran advokat secara sosiologis fungsional dan berkemanfaatan bagi masyarakat. ${ }^{34}$

\footnotetext{
${ }^{34}$ Jefry Tarantang, Advokat Mulia (Paradigma Hukum Profetik dalam Penyelesaian Sengketa Hukum Keluarga Islam), Yogyakarta: K-Media, 2018, h. 224-226.
} 
Nilai dasar etika advokat dalam penyelesaian sengketa hukum keluarga Islam tersebut kemudian dijabarkan melalui nilai instrumental yaitu Undang-UndangUndang Nomor 18 Tahun 2003 Tentang Advokat, dan Kode Etik Advokat Indonesia, serta perangkat hukum berupa aturan yang mengatur ketentuan hukum keluarga Islam, seperti Undang-Undang Nomor 7 Tahun 1989 Tentang Peradilan Agama, UndangUndang Nomor 3 Tahun 2006 Tentang Perubahan Undang-Undang Nomor 7 Tahun 1989 Tentang Peradilan Agama, Undang-Undang Nomor 50 Tahun 2009 Tentang Perubahan Kedua Undang-Undang Nomor 7 Tahun 1989 Tentang Peradilan Agama, Undang-Undang Nomor 1 Tahun 1974 Tentang Perkawinan, dan Instruksi Presiden Nomor 1 Tahun 1991 Tentang Kompilasi Hukum Islam.

Adapun nilai praksis etika advokat dalam penyelesaian sengketa hukum keluarga Islam nilai yang sesungguhnya dilaksanakan dalam kehidupan advokat dalam penegakan hukum, khususnya penyelesaian sengketa hukum keluarga Islam, seperti advokasi penyelesaian sengketa keluarga dengan menerapkan perdamaian, mengedepankan musyawarah, melakukan advokasi penyelesaian sengketa hukum keluarga Islam berdasarkan keadilan, jujur, profesional, amanah, dan memiliki kepribadian luhur sebagai profesi penegak hukum. ${ }^{35}$

Rumusan nilai dasar etika advokat dalam penyelesaian sengketa hukum keluarga Islam dapat dicontohkan dalam tabel berikut:

Tabel: Rumusan Nilai Dasar Etika Advokat

\begin{tabular}{|c|c|c|}
\hline Nilai Dasar & Nilai Instrumental & Nilai Praksis \\
\hline $\begin{array}{lr}\text { Ketuhanan } & \\
\text { (prinsip } & \text { perdamaian, } \\
\text { prinsip } a m a>n a>t & \text { dan adil, } \\
\text { prinsip } & \text { advokasi } \\
\text { penyelesaian } & \text { sengketa, } \\
\text { prinsip } & \text { penyelesaian } \\
\text { sengketa keluarga, dan } \\
\text { prinsip musyawarah) }\end{array}$ & 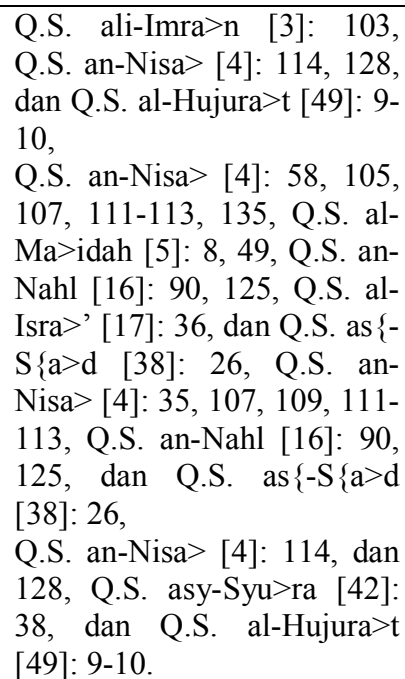 & \begin{tabular}{lr}
\multicolumn{3}{c}{ Advokat menjunjung tinggi } \\
sumpah jabatan, dan \\
bertakwa kepada Tuhan \\
Yang Maha \\
menjalankan Esa \\
dengan menjunjung tinggi \\
hukum Allah SWT.
\end{tabular} \\
\hline
\end{tabular}

${ }^{35}$ Jefry Tarantang, Menggali Etika Pengacara dalam Alquran, Jurnal Studi Agama dan Masyarakat Volume 11 Nomor 2, Desember 2015, h. 166. 


\begin{tabular}{|c|c|c|}
\hline & $\begin{array}{l}\text { Pasal } 4 \text { ayat (1) Undang- } \\
\text { Undang Nomor } 18 \text { Tahun } \\
2003 \text { tentang Advokat, Pasal } \\
2 \text { Kode Etik Advokat } \\
\text { Indonesia Tahun } 2002 \text {. }\end{array}$ & \\
\hline $\begin{array}{l}\text { Kemanusiaan } \\
\text { (prinsip advokasi } \\
\text { penyelesaian sengketa) }\end{array}$ & $\begin{array}{l}\text { Q.S. an-Nisa }>\text { [4]: } 35,107, \\
\text { 109, 111-113, Q.S. an-Nahl } \\
\text { [16]: 90, 125, dan Q.S. as }\{- \\
\text { S }\{a>d[38]: 26 . \\
\text { Pasal } 3 \text { huruf a dan huruf c } \\
\text { Kode Etik Advokat } \\
\text { Indonesia Tahun 2002. }\end{array}$ & $\begin{array}{l}\text { Advokat wajib } \\
\text { memperjuangkan hak azasi } \\
\text { manusia, dan tidak dapat } \\
\text { menolak memberi nasihat } \\
\text { atau bantuan hukum dengan } \\
\text { alasan karena perbedaan } \\
\text { agama, kepercayaan, suku, } \\
\text { keturunan, jenis kelamin, } \\
\text { keyakinan politik dan } \\
\text { kedudukan sosialnya. }\end{array}$ \\
\hline $\begin{array}{l}\text { Persatuan } \\
\text { (prinsip perdamaian dan } \\
\text { prinsip penyelesaian } \\
\text { sengketa keluarga) }\end{array}$ & $\begin{array}{l}\text { Q.S. ali-Imra }>\text { n }[3]: 103 \text {, } \\
\text { Q.S. an-Nisa }>\text { [4]: } 114,128 \text {, } \\
\text { dan Q.S. al-Hujura }>\text { t [49]: 9- } \\
\text { 10. } \\
\text { Pasal } 4 \text { ayat (2) Undang- } \\
\text { Undang Nomor } 18 \text { Tahun } \\
\text { 2003 tentang Advokat. }\end{array}$ & $\begin{array}{l}\text { Advokat memegang teguh } \\
\text { dan }\end{array} \begin{array}{l}\text { mengamalkan } \\
\text { Pancasila dan UUD } 1945\end{array}$ \\
\hline $\begin{array}{l}\text { Kerakyatan (musyawarah) } \\
\text { (prinsip musyawarah) }\end{array}$ & $\begin{array}{l}\text { Q.S. asy-Syu>ra [42]: } 38 \text {, } \\
\text { dan Q.S. al-Hujura>t [49]: 9- } \\
10 . \\
\text { Pasal } 4 \text { huruf a Kode Etik } \\
\text { Advokat Indonesia Tahun } \\
2002 .\end{array}$ & $\begin{array}{lr}\text { Advokat } & \text { mengutamakan } \\
\text { jalan damai dalam } & \text { penyelesaian r sengketa } \\
\text { hukum keluarga Islam }\end{array}$ \\
\hline $\begin{array}{l}\text { Keadilan } \\
\text { (prinsip } \quad a m a>n a>t \quad \text { dan } \\
\text { adil) }\end{array}$ & $\begin{array}{l}\text { Q.S. an-Nisa }>\text { [4]: 58, 105, } \\
\text { 107, 111-113, 135, Q.S. al- } \\
\text { Ma>idah [5]: 8, 49, Q.S. an- } \\
\text { Nahl [16]: 90, 125, Q.S. al- } \\
\text { Isra>' [17]: 36, dan Q.S. as \{- } \\
\text { S \{a>d [38]: 26. } \\
\text { Pancasila dan Pasal } 27 \text { ayat } \\
\text { (1), dan Pasal 28D ayat (1) } \\
\text { UUD 1945, Pasal } 4 \text { ayat (2) } \\
\text { Undang-Undang Nomor 18 } \\
\text { Tahun 2003 tentang } \\
\text { Advokat, Pasal } 2 \text { Kode Etik } \\
\text { Advokat Indonesia Tahun } \\
\text { 2002. }\end{array}$ & $\begin{array}{l}\text { Advokat bertindak adil, } \\
\text { jujur, bertanggung jawab } \\
\text { berdasarkan hukum dan } \\
\text { keadilan dan dilandasi } \\
\text { moral yang tinggi dan luhur } \\
\text { dalam penyelesaian } \\
\text { sengketa hukum keluarga } \\
\text { Islam }\end{array}$ \\
\hline
\end{tabular}

\section{Kesimpulan}

Cita hukum (rechtsidee) dan sistem nilai etika advokat merumuskan nilai dasar etika advokat yang terdiri dari nilai-nilai moral dan nilai-nilai etik. Oleh karena itu selain menjalankan profesi berdasarkan hukum positif harus menjunjung tinggi Alqura. Rumusan nilai dasar etika advokat yang menjadi sumber nilai dalam peraturan hukum konkret sebagaimana terdapat dalam Undang-Undang Nomor 18 Tahun 2003 tentang Advokat, dan Kode Etik Advokat Indonesia Tahun 2002 dan peraturan perundang-udangan yang berlaku sebagai pedoman advokat dalam penyelesaian sengketa hukum keluarga Islam. Nilai dasar etika advokat dalam penyelesaian 
sengketa hukum keluarga Islam yaitu Pancasila kemudian dijabarkan melalui nilai instrumental yaitu Undang-Undang-Undang Nomor 18 Tahun 2003 Tentang Advokat, dan Kode Etik Advokat Indonesia, serta perangkat hukum kemudia menjadi nilai praksis dengan mensistematisasi moralitas advokat sesuai dengan nilai dasar etika advokat dalam penyelesaian sengketa keluarga Islam.

\section{DAFTAR PUSTAKA}

Anthon F. Susanto, Dekonstruksi Hukum Eksplorasi Teks dan Model Pembacaan, Yogyakarta: Genta Publishing, 2010.

Ayi Sofyan, Kapita Selekta Filsafat, Bandung: Pustaka Setia, 2010.

Bernard L. Tanya, dkk, Teori Hukum Strategi Tertib Manusia Lintas Ruang dan Generasi, Yogyakarta: Genta Publishing, 2010.

Cecep Sumarna, Rekonstruksi Ilmu: dari Empirik-Rasional Ateistik ke Empirik Rasional Teistik, Bandung: Benang Merah Press, 2005.

Didi Kusnadi, Bantuan Hukum dalam Islam Profesi Kepengacaraan dalam Islam dan Prakteknya, Bandung: Pustaka Setia, 2012.

A. Djazuli, Kaidah-kaidah Fikih: Kaidah-kaidah Hukum Islam dalam Menyelesaikan Masalah-Masalah yang Praktis, Jakarta: Kencana, 2007.

Henry Pandapotan Panggabean, Manajemen Advokasi, Bandung: Alumni, 2012.

Imam Musbikin, Qawa'id al-fiqhiyah, Jakarta: PT. RajaGrafindo Persada, 2001.

J.J. H. Bruggink, Refleksi tentang Hukum, diterjemahkan oleh Arief Sidharta dari buku asli yang berjudul "Rechtsreflecties", Bandung: Citra Aditya Bakti, 1999.

Jasser Auda, Membumikan Hukum Islam Melalui Maqasid Syariah, diterjemahkan oleh Rosidin dan 'Ali 'Abd el-Mun'im dari buku asli berjudul "Maqasid Shariah as Philosophy of Islamic Law: A System Approach”, Bandung: Mizan Pustaka, 2015.

Jefry Tarantang, Advokat Mulia (Paradigma Hukum Profetik dalam Penyelesaian Sengketa Hukum Keluarga Islam), Yogyakarta: K-Media, 2018.

Jefry Tarantang, Menggali Etika Pengacara dalam Alquran, Jurnal Studi Agama dan Masyarakat Volume 11 Nomor 2, Desember 2015.

Jefry Tarantang, Penyelesaian Sengketa Melalui Lembaga Arbitrase, Jurnal Al-Qordh Volume 4, Nomor 2, 2018.

Jefry Tarantang, Teori dan Aplikasi Pemikiran Kontemporer dalam Pembaharuan Hukum Keluarga Islam, Jurnal Transformatif Vol. 2, No. 1, April 2018.

Lawrence M. Friedman, Sistem Hukum Perspektif Sosial, diterjemahkan oleh M. Khozim dari buku asli berjudul "The Legal System: A Social Science Perspective", Bandung: Nusa Media, 2015.

Montesquieu, The Spirit of Laws Dasar-Dasar Ilmu Hukum dan Ilmu Politik, diterjemahkan oleh M. Khoiril Anam dari buku asli berjudul "The Spirit of Laws", Bandung: Nusa Media, 2015.

Muhammad Nuh, Etika Profesi Hukum, Bandung: Pustaka Setia, 2011.

Philippe Nonet, dan Philip Selznick, Hukum Responsif, diterjemahkan oleh Raisul Muttaqien dari buku asli berjudul "Law and Society in Transition: Toward Responsive Law", Bandung: Nusa Media, 2013.

Philipus M. Hadjon, dan Tatiek Sri Djatmiati, Argumentasi Hukum, Yogyakarta: Gajah Mada University Press, 2016. 
El-Mashlahah, Vol. 9, No. 2, 2019

A. Ridwan Halim, Bendera Mimbar Filsafat Hukum Indonesia dan Pragmatisasinya (Suatu Analisis Yuridis Empiris), Jakarta: Angky Pelita Studyways, 2004.

Satjipto Rahardjo, Hukum Progresif Sebuah Sintesa Hukum Indonesia, Yogyakarta: Genta Publishing, 2009.

Shidarta, Moralitas Profesi Hukum Suatu Tawaran Kerangka Berpikir, Bandung: Refika Aditama, 2009.

Sirajuddin, Perda Berbasis Norma Agama, Jakarta: Rajawali Pers, 2015.

Sudikno Mertokusumo, Penemuan Hukum, Yogyakarta: Universitas Atma Jaya, 2010.

Sudikno Mertokusumo, Teori Hukum, Yogyakarta: Cahaya Atma Pustaka, 2012.

Thomas E. Davitt, Nilai-Nilai Dasar di dalam Hukum Menganalisa ImplikasiImplikasi Legal-Etik Psikologi \& Antropologi bagi Lahirnya Hukum, Yogyakarta: Pallmal, 2012.

Zainuddin Ali, Hukum Islam (Pengantar Hukum Islam di Indonesia), Jakarta: Sinar Grafika, 2008. 